\title{
DYNAMICS OF FEMALE FERTILITY IN INDONESIA, THAILAND AND THE PHILIPPINES, 1980-2014
}

\author{
${ }^{1}$ Sharifah Nur Syafiqah Binti Syed Omar, ${ }^{*}{ }^{2}$ Thirunaukarasu Subramaniam, ${ }^{* *}$ \\ ${ }^{3}$ Mazlan Majid \& ${ }^{4}$ Nanthakumar Loganathan \\ ( ${ }^{*}$ First author, ${ }^{* *}$ Corresponding author) \\ 1,2,3 Department of Southeast Asian Studies, Faculty of Arts and Social Sciences \\ University of Malaya \\ ${ }^{4}$ Azman Hashim International Business School, Universiti Teknologi Malaysia \\ (sharifah.epah@um.edu.my, stkarasu@um.edu.my,mazlanmajid@um.edu.my, \\ n4nantha@yahoo.com) \\ Doi: https://doi.org/10.22452/ jati.sp2018no1.4
}

\begin{abstract}
ASEAN-3 countries displayed a high fertility rate and infant mortality rate in the beginning of the formation of ASEAN in 1967, but towards the end of the $20^{\text {th }}$ century and the beginning of the $21^{\text {st }}$ century, there is a reversal of this pattern. Literature review on the determinants of female fertility reveals the importance of infant mortality, income, female secondary education, female employment and age dependency as key determinants of female fertility. This study, therefore, attempts to identify the determinants of female fertility for the ASEAN-3 countries, namely Indonesia, Thailand and the Philippines. Firstly, using the Johansen cointegration method, we identified the presence of a long-run relationship between female fertility rate, infant mortality, income, female secondary education, female employment and age dependency ratio for all three countries. Secondly, weidentified three major determinants of female fertility for Indonesia as female education, age dependency ratio and infant mortality which is in line with the theory. For Thailand, two main determinants of female fertility include female education and income. For the Philippines, two important variables that determine female fertility are female employment and infant mortality. Finally, we found a deviation of fertility rate from the short-run to the long-run equilibrium for those three countries, with the highest and lowest speed of adjustment recorded for the Philippines and Indonesia, respectively.
\end{abstract}

Keywords: female fertility, secondary education, female employment, age dependency ratio, cointegration 


\section{Introduction}

Association of Southeast Asian Nation (ASEAN) comprises ten countries namely Brunei, Cambodia, Indonesia, Laos, Malaysia, Myanmar, Philippines, Singapore, Thailand and Vietnam. Two most prominent demographic characteristics in Southeast Asian countries are both high fertility and high infant mortality rate, but this trend seems to dissipate. The total fertility rate in Southeast Asia in the late 1980s was 3.8 births per woman whilein 2008 the fertility ratedeclined to 2.3 births per woman (Teguh, 2009). Data from World Development Indicators (WDI) indicate that Singapore has the lowest fertility rate followed by Thailand and Malaysia. However, the Philippines' female fertility rate remains high in comparison to other Southeast Asian countries.

Gubhaju (2007) stated that there are five levels of Total Fertility Rate (TFR) namely high (TFR $\geq 5$ ), transitional (TFR 3.0 to 4.9), near-replacement (TFR 2.2 to 2.9), low (TFR 1.6 to 2.1 ) and critically low (TFR $\leq 1.5$ ). Table 1 shows that there was a significant decline in Thailand's fertility rate during the periods from 1970-1975 and 1990-1995. Singapore also exhibited a dramatic decline in fertility rate from 6.4 (the period from 1950-1955) to 2.6 (period from 1970-1975) and continued to experience a further decline in female fertility, reaching 1.4 (the period from 2000 to 2005). As of 2005, the fertility level of the Philippines is transitional level, followed by Indonesia in near-replacement level, while Thailand is encountering a low level of female fertility and Singapore at the critically low level.

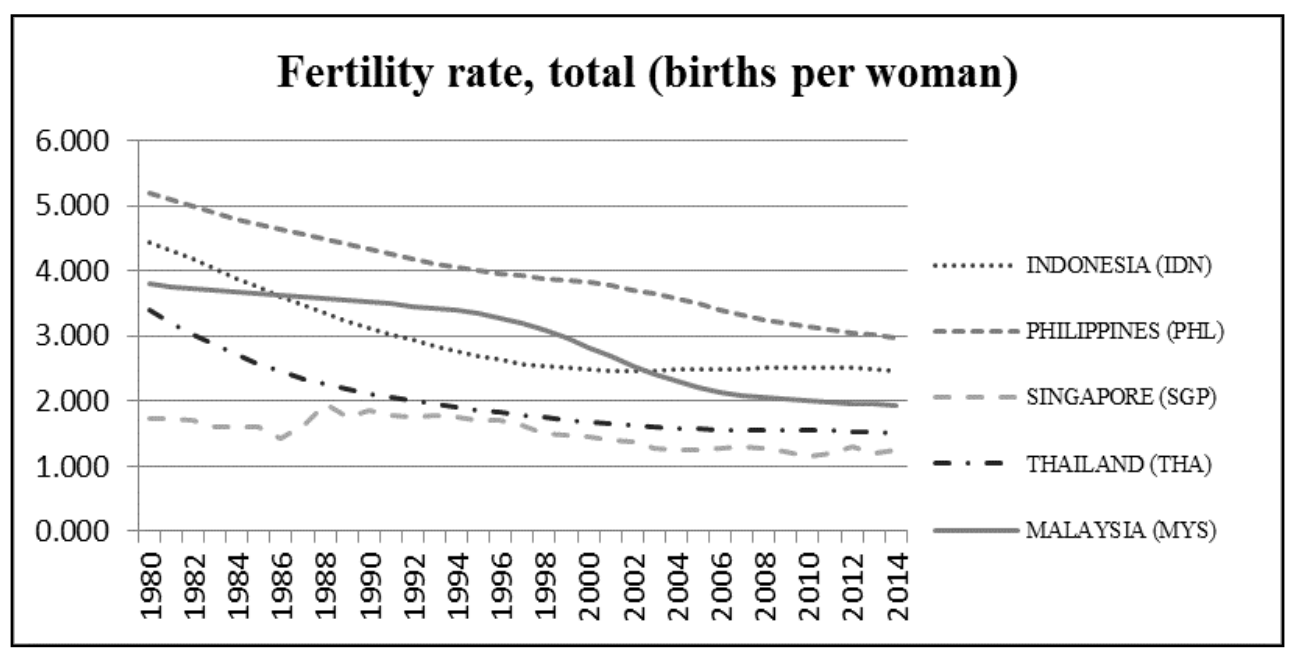

Figure 1: Fertility rate of ASEAN-5

Source: World Development Indicators (2017). 
This study aims to identify the key determinants of female fertility rate in Indonesia, Thailand and the Philippines. These three countries have similar development characteristics, especially in terms of its economic development. As such, this study attempts to identify a selected number of factors that may influence the female fertility rate. The possible determinants include infant mortality, GDP per capita, female secondary education, female employment and age dependency ratio. The key objectives of this study, therefore, are as follows. First objective is to study the presence of the long run relationship between female fertility rates and the chosen macroeconomic variables in Indonesia, Thailand and the Philippines. Secondly, to study the determinants of female fertility rate for Indonesia, Thailand and the Philippines. Thirdly, to analysehow fast the economy adjusts to equilibrium following a shock based on the speed of adjustment. Thus, this paper is organized as follows. The next section divulges the fertility theories and literature reviews related to this study. The third section elaborates on the data source and model specification as well as empirical strategies. The fourth section discusses the results and the final section concludes.

\section{Literature Review}

The theory of demographic transition dominates the debate on fertility decline (Szreter, 1993). Demographic transition theory states that people in the rural community tend to havea higher number of children. According to Schultz (2001), the demographic transition refers to a sequence of three periods. The first period is when both the fertility and mortality rates are high. In the second period, mortality rate tends to decrease, raising life expectancy while the fertility rate is still high. Fertility rate then begins to decline during the third period, where the number of births per women falls more than half. Classical demographic transition theory attributes the fertility decline to themigration of people from rural to urban areas. When historically high levels of fertility have declined by more than 10 percent, they are not expected to rise again on a sustained basis (National Research Council, 2000).

The Economic Theories of Fertility proposed by Becker (1960) stated that for most parents, children are viewed merely as durable goods, primarily a consumer's durable, which yields income and gives satisfaction to parents. Becker argued that child mortality has fallen so low that the ordinary changes in income have very little effect on the number of survivors for a given birth cohort. Moreover, it is doubtful that even a large decline in child mortality would have significant effect on family size as parents are more in terested in survivors and not in the number of births. As such, a decline in child mortality tends to induce a 
corresponding decline in births. De Tray (1973) too viewed children as durable assets and introduce quality dimension in analysing demand for children. Therefore, households have options to either increase thenumbers of children they want to have (quantity) or increase the resource investment (quality) in the lives of existing children.

Several studies focused on the relationship between female fertility rate and infant mortality. Friedlander and Silver (1967), using the cross-section data of 85 countries found that there exists a positive and significant relation between female fertility and infant mortality. Analysis by Yamada (1985) using time series methodology also found that a decline in infant mortality triggers a subsequent decline in female fertility. This findings are also supported by Panopoulou and Tsakloglou (1999) and Subramaniam, Loganathan and Devadason (2018). Furthermore, Yamada (1985) stated that the decrease in infant mortality is caused by the increase in real income per capita in the first place. Defo (1998) found that child deaths reduce the length of birth intervals and increase the probability of conceiving a subsequent child indicating a positive relationship between female fertility and child mortality.

One of the most accepted demographic theories is that when income increased, fertility rate tends to decrease. Narayan and Peng (2003) found that income impacts negatively on the female fertility rate in China. Their analysis proved that the fertility decline in China is caused mainly due to its socioeconomic development rather than the implementation of China's one child policy. However, this observation has been challenged by Panopoulou and Tsakloglou (1999) who found a positive relationship between female fertility rates and economic development. However, a study done by Myrskylä, Kohler, and Billari (2009) indicated that the relationship between development and fertility tends to change from negative to positive. The change is observed to happen only at high levels of socioeconomic development, as measured by the Human Development Index (HDI). The study also shows that the positive association is driven by olderage fertility and emerges only in countries with comparatively high gender equality. Likewise, for ASEAN-5, Subramaniam et al. (2018) found that the female fertility rate and GDP per capita is negatively related for Indonesia while for Malaysia it is positively related.

In addition, Teguh's (2009) study on Southeast Asian and South Asian countries found that income per capita is positively correlated with female fertility rate, but with two years lag. For example, Teguh highlighted that the 2008 total fertility rate was influenced by the 2006 income per capita and consumer price index, with higher income couples are able to bear more children. Moreover, Teguh stated that in Islamic countries a man is able to practice polygamy if he has 
the ability to support his wives. Consequently, an increase in income tend to lead to polygamy practice, thus increasing the fertility rate. Al-Qudsi (1998) who estimated the impact of cultural factors on demand for children seems to agree with Teguh where in Arabic countries, a high fertility rate goes together with high income. As the majority of the population in Arabic countries are Moslems, they believe producing more children will enable them to obtain sustenance.

The education of parents is usually found to be one of the prominent factors in explaining fertility change (Cochrane, 1979). Various reasons could explain why the education of parents may influence the intervening variables. First, education is more likely to have an inverse impact on exposure. It increases the age at marriage either because marriage is likely to be delayed due to schooling and subsequent employment, or because it takes educated people longer time to find a suitable spouse (Shapiro, 1996). Better educated women also tend to have better jobs and earn higher incomes, thus the forgone earnings from taking care of children would be higher for these women which in turn reduces female fertility (Kim, 2016).Friedlander and Silver (1967) who used illiteracy as a proxy for education also found a direct relationship between illiteracy and female fertility. Panopoulou and Tsakloglou (1999) too found that education gives a negative impact on the female fertility rate.

While the inverse relationship between female education and female fertility has been one of the most consistent findings in the literature, the relationship does vary, especially in rural areas (Cochrane, 1979). A widely cited case has been the U-shaped relationship between education and female fertility in Indonesia. Women with some level of primary or middle school experience had higher fertility in comparison to women with no schooling or with 12 or more years (Cobbe \& Boediono, 1993; Hull \& Hull, 1977). However, by the 1980s, the inverted U-shaped pattern of fertility by women's schooling began to flatten out and eventually disappear, especially in urban areas (Maralani, 2008).

Da Rocha and Fuster (2006) research on OECD countries found that the labour market frictions determine how employment and female fertility are associated across economies. When there is a low probability of finding a job, female fertility and employment are positively associated. However, it becomes negative correlated when the employment rates are high. They concluded that in countries where women participate in the labour market, labour market frictions are key for understanding the behaviour of fertility rates. Van den Broeck and Maertens (2014) analysed the impact of female wage employment on fertility rates. They did a case study in Senegal, where during the last decade the horticultural export has boomed and has tremendously increased off-farm employment opportunities for rural women. Their analysis used wage employment and found 
that it negatively affects fertility rate. The study also found that the effect of employment on fertility is strongest for illiterate women. Conversely, Panopoulou and Tsakloglou (1999) using female labour force participation as a proxy for employment failed to find a significant relationship with female fertility. Subramaniam et al. (2018) analysis on ASEAN-5 found a significant relationship only for thePhilippines, with female labour force participation rate directly related to the fertility rate.

Hock and Weil (2012) analysed the dynamic evolution of a country's population age structure and fertility rate by focusing on old age dependency. They concluded that in a country with a high level of old age dependency, a large fraction of the working populations income will be redistributed to the elderly. Due to this, the working age individuals will want to raise a lower number of children thus lowering fertility. On the other hand, Bryant, Faruqee, Velculescu and Arbatli (2004) concentrated their research of dependency on the younger population and their open-economy aspects. They found that the consumptionsaving behaviour of individual adults who provide in-vivo transfers to children differs significantly from the behaviour of otherwise identical individuals without financial responsibilities for child support. As lower fertility rates reduce the financial burden on existing adults, resources are freed for the purpose of additional consumption and saving.

\section{Model Specification and Methodology}

The empirical analysis incorporates six variables which will be used in this study. Data on female fertility rate, infant mortality rate, real per capita gross domestic product, female gross secondary education, female employment in the services sector and age dependency ratio are compiled for Indonesia, Thailand and the Philippines. The period of analysis is from 1980-2014 for Indonesia and the Philippines, and 1980-2013 for Thailand. All data series were extracted from World Development Indicators (2017). Based on Narayan and Peng (2003) and Subramaniam et al. (2018), a model is developed to estimate the determinants of female fertility. The female fertility model is thus expressed in the following functional form:

$$
F R_{t}=f\left(L M_{t}: G D P_{t}, E R_{f}, S E_{f}, A D R_{t}\right)
$$

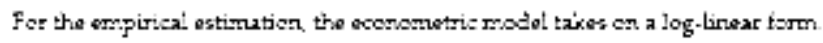

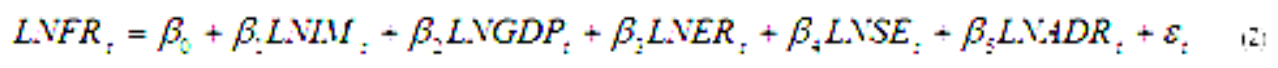


where $\varepsilon_{t}$ is the stochastic error term and $\beta_{0}$ is the intercept term. All variables used in this study are defined below:

$\mathrm{FR}=$ to tal fertility rate (number of children that would be born to a woman if she were to live to the end of her childbearing years and bear children in accordance with age-specific fertility rates of the specified year)

$\mathrm{IM}=$ infant mortality rate (number of infants dy ing before reaching one year of age, per 1,000 live births in a given year)

GDP = real per capita GDP (in constant 2010 U.S. dollars)

$E R=$ female secondary educ ation gross enrollment ratio (female ratio of to tal enrollment, reg ardless of age, to the population of the age group that officially corresponds to secondary education)

$\mathrm{SE}=$ female employ ment in service ratio (working age who were engaged in any activity to produce goods or provide services for pay or profit, whether at work during the reference period or not at work due to temporary absence from a job, or to the working-time arrangement)

$\mathrm{ADR}=$ age dependency ratio (ratio of dependents to the working-age population)

When we apply cointegration analysis, the first step involves determining the order of lag length based on the vector autoregressive (VAR) estimates. As suggested by Juselius (1996), we begin with one lag in order to ensure that the residual is free from the problem of autocorrelation. As the data used are annual, we find that in most cases, onelag is sufficient to yield a VAR model with residuals free of autocorrelation (Subramaniam \& Baharumshah, 2011). As the variables under study for all three countries namely Indonesia, Thailand and thePhilippines are integrated at most of order one, we extended our analysis with the Johansen procedure of testing as proposed by Masih and Masih (1999) to check for the presence of multiple cointegrating vectors. The main aim of performing the multivariate Johansen cointegration test is to verify the existence of the long-run relationship between the series used in this study.

As we obtain the cointegrating vector from the Johansen-Juselius procedure, the short-run vector autoregression in an error correction model can be stated as follows following Engle and Granger (1987):

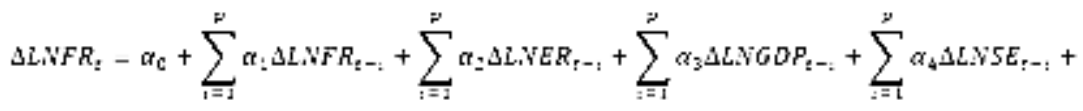

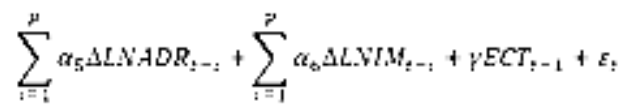


Where, $\alpha_{0}$ is the constant which indicates intercept; $\Delta$ is a difference operator; ECT $t-1$ is the error correction term that was obtained from cointegration relationship which is normalized with respect to each variable; $\alpha$ is the coefficient that indicates the measure of speed of adjustment back to long-run equilibrium relationship and $\varepsilon_{t}$ is the serially uncorrelated random error terms which has zero mean. The analysis is extended further to obtain the error correction model. Baharumshah, Lau and Khalid (2006) proposed that applying correction factor for the cointegration procedure in a small sample is more likely to reduce the possibility of the test to falsely reject the null hypothesis of no cointegration when we deal with the relatively short span of data. The ultimate aim of examining the short-run relationship is to comprehend how the speed of adjustment component adjusts to equilibrium following a shock. A significant error correction term will in dicate the existence of causality at least in one direction (Granger, 1986).

\section{Empirical Results and Discussion}

\section{Descriptive statistics}

Table 1 presents the descriptive statistics for Indonesia, Thailand and the Philippines. By comparing the mean of female fertility rate (FR) for those three countries, the Philippines has the highest rate of female fertility at almost 4 children per woman. This is followed by Indonesia and Thailand. The Philippines also has the highest mean for gross secondary education enrollment of female (ER), whileIndonesia has thelowest mean. Among those threecoun tries, Thailand can be identified to have a higher economic growth compared to Indonesia and the Philippines. This is shown through its highest GDP per capita mean (RGDP) at more than USD3000. On the other hand, the Philippines has the lowest GDP per capita mean at barely USD1700. However, the Philippines' women participate actively in the services sector (SE) at the mean of 59.15, as compared to Indonesia and Thailand both barely reaches the mean of 30. The Philippines has the highest age dependency ratio (ADR), followed by Indonesia and Thailand. This indicates that the Philippines' working population has more economic responsibilities. In terms of infant mortality rate (IM), Indonesia has a mean of almost 50, followed by the Philippines at a mean of 35 and Thailand at approximately 25. 
Table 1: Descriptive statistics

\begin{tabular}{lcccccc}
\hline & $F R$ & $E R$ & $R G D P$ & $S E$ & $A D R$ & $I M$ \\
\hline Indonesia & & & & & & \\
Mean & 2.947 & 51.367 & 2160.343 & 38.778 & 61.367 & 49.826 \\
Median & 2.575 & 48.781 & 2143.390 & 38.800 & 58.388 & 46.700 \\
Maximum & 4.430 & 82.162 & 3703.366 & 53.167 & 80.722 & 85.400 \\
Minimum & 2.463 & 21.711 & 1095.787 & 28.900 & 49.458 & 23.600 \\
Std. Dev. & 0.620 & 17.735 & 740.490 & 6.523 & 10.117 & 19.351 \\
Jarque-Bera & 7.357 & 1.540 & 1.566 & 2.125 & 3.514 & 2.694 \\
& $(0.025)$ & $(0.463)$ & $(0.457)$ & $(0.346)$ & $(0.173)$ & $(0.260)$ \\
\hline Philippines & & & & & & \\
Mean & 3.961 & 78.286 & 1723.645 & 59.148 & 73.055 & 35.323 \\
Median & 3.923 & 77.656 & 1620.206 & 58.900 & 73.640 & 31.800 \\
Maximum & 5.183 & 93.949 & 2531.917 & 70.656 & 86.304 & 53.200 \\
Minimum & 2.977 & 65.176 & 1380.682 & 46.900 & 58.028 & 22.800 \\
Std. Dev. & 0.642 & 8.715 & 302.482 & 6.945 & 8.377 & 10.090 \\
Jarque-Bera & 1.611 & 2.298 & 7.925 & 1.952 & 1.876 & 3.700 \\
& $(0.447)$ & $(0.317)$ & $(0.019)$ & $(0.377)$ & $(2.006)$ & $(0.157)$ \\
\hline Thailand & & & & & & \\
Mean & 1.9995 & 51.770 & 3305.248 & 32.297 & 50.441 & 24.815 \\
Median & 1.802 & 48.045 & 3417.921 & 31.550 & 46.918 & 22.200 \\
Maximum & 3.392 & 89.943 & 5612.691 & 45.700 & 76.002 & 47.000 \\
Minimum & 1.524 & 25.880 & 1403.696 & 18.100 & 38.815 & 11.200 \\
Std. Dev. & 0.530 & 23.242 & 1285.700 & 8.330 & 10.896 & 10.951 \\
Jarque-Be ra & 8.016 & 3.415 & 1.776 & 3.040 & 4.905 & 2.943 \\
& $(0.018)$ & $(0.181)$ & $(0.411)$ & $(0.219)$ & $(0.086)$ & $(0.230)$ \\
\hline
\end{tabular}

Note: Figures in ( ) represents the probability values.

\section{Unit root tests}

A time series is said to be stationary if a shift in time does not cause a change in the shape of the distribution, having mean, variance and covariance which are constant over time. The unit root test is a test for stationarity in time series. A time series is non-stationary if a unit root exists. The time series needs to be nonstationary as the trend of the variables are analyzed over the years. Table 2 summarizes the Zivot-Andrews (ZA) unit root test with a single break at an unknown point with an intercept of a linear trend in Indonesia, Thailand and the Philippines. We found that the order of integration is at $I(1)$ with unknown, various single structural break dates. 
Table 2: Zivot and Andrews unit root test results ASEAN

\begin{tabular}{lcc}
\hline & ZA-stat & Break date $\left(T_{\mathrm{B}}\right)$ \\
\hline Indonesia (1980-2014) & & \\
LNFR & $-5.798^{*}$ & 1993 \\
LNER & $-5.209^{* *}$ & 2007 \\
LNGDP & $-11.209^{*}$ & 1998 \\
LNSE & $-9.413^{*}$ & 2006 \\
LNADR & $-5.966^{*}$ & 1998 \\
LNIM & $-5.097^{* *}$ & 1988 \\
\hline Philippines (1980-2014) & & \\
LNFR & $-14.113^{*}$ & 1994 \\
LNER & $-5.254^{* *}$ & 1990 \\
LNGDP & $-6.154^{*}$ & 2002 \\
LNSE & $-5.089^{* *}$ & 2000 \\
LNADR & $-5.651^{*}$ & 2001 \\
LNIM & $-9.318^{*}$ & 1989 \\
\hline Thailand (1980-2013) & & \\
LNFR & $-5.401^{* *}$ & 1991 \\
LNER & $-4.906^{* * *}$ & 2002 \\
LNGDP & $-5.143^{* *}$ & 1997 \\
LNSE & $-4.980^{* * *}$ & 1993 \\
LNADR & $-4.957^{* * *}$ & 2006 \\
LNIM & $-5.438^{* *}$ & 2007 \\
\hline
\end{tabular}

Note: ${ }^{*}{ }^{* *}$ and ${ }^{* * *}$ denote statistical significance at $1 \%, 5 \%$ and $10 \%$ respectively.

\section{Johansen cointegration tests}

The purpose of the cointegration analysis is to estimate and test stationary linear relations, or cointegration relations, between non-stationary time series variables. When two or more non-stationary time series possess the same order of integration, and a linear combination of these series is found to be stationary, we can thus conclude that there is cointegration. We performed the Johansen multivariate cointegration test to verify the existence of a long-run relationship. The trace and the maximal eigen value test is employed to confirm the existence of a long-run relationship as proposed by Johansen and Juselius (1990). The cointegration test results are reported in Table 3. The results of the Johansen cointegration test affirms that the null hypothesis of no cointegrating vector is rejected for all three countries studied at the 1 percent level of significance as per the results obtained from the trace test. The maximal eigenvalue test result is also found to be somewhat consistent with the results from the trace test, where both statistics are found to be greater than its critical values. As such, we can conclude that there is at least one cointegrating relationship for all three countries. As such, 
we can conclude that there is a long-run integration between various series investigated in this study.

Table 3: Johansen Cointegration Test

\begin{tabular}{ccccc}
\hline Hypothesized & \multicolumn{2}{c}{ Trace } & \multicolumn{2}{c}{ Max Eigen } \\
\cline { 2 - 5 } No. of CE(s) & Statistics & CV $(95 \%)$ & Value & CV $(95 \%)$ \\
\hline Indonesia & & & & \\
$r=0$ & $194.699^{*}$ & 95.754 & $90.026^{*}$ & 40.078 \\
$r \leq 1$ & $104.673^{*}$ & 69.819 & $43.834^{*}$ & 33.877 \\
$r \leq 2$ & $60.839^{*}$ & 47.856 & 25.748 & 27.584 \\
$r \leq 3$ & $35.090^{*}$ & 29.797 & 21.816 & 21.132 \\
$r \leq 4$ & 13.275 & 15.494 & 13.145 & 14.265 \\
$r \leq 5$ & 0.129 & 3.841 & 0.129 & 3.841 \\
\hline Philippines & & & & \\
$r=0$ & $238.281^{*}$ & 95.754 & $80.215^{*}$ & 40.078 \\
$r \leq 1$ & $158.066^{*}$ & 69.819 & $68.157^{*}$ & 33.877 \\
$r \leq 2$ & $89.909^{*}$ & 47.856 & $41.661^{*}$ & 27.584 \\
$r \leq 3$ & $48.248^{*}$ & 29.797 & $24.896^{*}$ & 21.132 \\
$r \leq 4$ & $23.352^{*}$ & 15.495 & $19.736^{*}$ & 14.265 \\
$r \leq 5$ & 3.616 & 3.841 & 3.616 & 3.841 \\
\hline Thailand & & & & \\
$r=0$ & $206.168^{*}$ & 95.754 & $78.905^{*}$ & 40.078 \\
$r \leq 1$ & $127.262^{*}$ & 69.819 & $44.449^{*}$ & 33.877 \\
$r \leq 2$ & $82.813^{*}$ & 47.856 & $36.125^{*}$ & 27.584 \\
$r \leq 3$ & $46.688^{*}$ & 29.797 & $31.634^{*}$ & 21.132 \\
$r \leq 4$ & 15.054 & 15.495 & $14.629^{*}$ & 14.265 \\
$r \leq 5$ & 0.424 & 3.841 & 0.424 & 3.841 \\
\hline
\end{tabular}

Note: * denote statistical significance at the $5 \%$ level

Meanwhile, the error correction term (ECT) suggests that those three countries have the varying speed of adjustments (see Table 4). The negative and significant lagged ECT values prove that the long-run relationship established is stable as suggested by Bannerjee et al. (1988). The deviation of the fertility rate from short-run to the long-run is corrected by 0.104 (approximately 10 percent) for the Philippines, the country with the highest speed of adjustment. On the other hand, Indonesia records the lowest speed of adjustment which is only 0.008 (approximately almost 1 percent) while Thailand recorded an ECT of 0.021 (approximately 2 percent). Several diagnostic tests were performed to prove that the residuals have the desirable statistical properties. We performed Normality test and the Jacque-Bera statistic reveals that the residuals are normally distributed. Secondly, the Breusch-Godfrey Serial Correlation test reveals that the 
model does not suffer from autocorrelation problems. Finally, the ARCH test done reveals that no strong evidence of heteroskedasticity.

Table 4: Error Correction Model Results

\begin{tabular}{|c|c|c|c|}
\hline \multirow[t]{2}{*}{ Variable } & $\begin{array}{c}\text { Indonesia } \\
\text { (1980-2014) }\end{array}$ & $\begin{array}{l}\text { Philippines } \\
\text { (1980-2014) }\end{array}$ & $\begin{array}{c}\text { Thailand } \\
(1980-2013)\end{array}$ \\
\hline & \multicolumn{3}{|c|}{ Dependent variable: $\triangle L N F R$} \\
\hline \multirow[t]{2}{*}{ Intercept } & -0.000 & $0.003^{* * *}$ & 0.001 \\
\hline & {$[-0.677]$} & [3.569] & {$[0.490]$} \\
\hline \multirow[t]{2}{*}{$\triangle L N F R$} & $1.021^{* * *}$ & $1.371^{* * *}$ & $1.046^{* * *}$ \\
\hline & [ 100.143] & [ 28.099] & [ 49.116] \\
\hline \multirow[t]{2}{*}{$\triangle L N E R$} & {$[-1.110]$} & -0.006 & -0.009 \\
\hline & -0.002 & {$[-1.528]$} & {$[-1.577]$} \\
\hline \multirow[t]{2}{*}{$\triangle L N G D P$} & 0.001 & $0.008^{* *}$ & 0.004 \\
\hline & {$[0.617]$} & [ 2.223] & [ 1.119] \\
\hline \multirow[t]{2}{*}{$\triangle L N S E$} & $-0.002^{* *}$ & -0.001 & -0.002 \\
\hline & {$[-2.181]$} & {$[-0.171]$} & {$[-0.820]$} \\
\hline \multirow[t]{2}{*}{$\triangle L N A D R$} & $-0.051^{*}$ & $-0.264^{* * *}$ & 0.021 \\
\hline & {$[-1.850]$} & {$[-10.599]$} & {$[0.817]$} \\
\hline \multirow[t]{2}{*}{$\Delta L N I M$} & $-0.017^{*}$ & 0.001 & -0.056 \\
\hline & {$[-1.801]$} & {$[0.077]$} & {$[-1.273]$} \\
\hline \multirow[t]{2}{*}{$E C T_{t-1}$} & $-0.008^{* * *}$ & $-0.104^{* * *}$ & $-0.021^{* * *}$ \\
\hline & {$[-17.520]$} & {$[-8.559]$} & {$[-6.211]$} \\
\hline \multirow[t]{2}{*}{ Adj. $R^{2}$} & 0.999 & 0.9788 & 0.998 \\
\hline & $\begin{array}{c}0.858 \\
(0.651)\end{array}$ & $\begin{array}{c}0.744 \\
(0.689)\end{array}$ & $\begin{array}{c}0.548 \\
(0.760)\end{array}$ \\
\hline$\chi_{\text {Normality }}$ & 0.002 & 0.485 & 0.251 \\
\hline$\chi_{\text {Serial correlation }}$ & $(0.997)$ & $(0.622)$ & $(0.780)$ \\
\hline \multirow{2}{*}{$\chi_{A R C H}$} & 1.516 & 0.458 & 3.112 \\
\hline & $(0.228)$ & (0.504) & $(0.088)$ \\
\hline
\end{tabular}

Note: ${ }^{* * *}$ and ${ }^{* * *}$ denote statistical significance at $1 \%, 5 \%$ and $10 \%$ respectively. 


\section{Long-Run Equation}

From the coin tegration analysis, we found that there exists a long-run relationship between female fertility rates (LNFR) and its determinants namely female secondary education enrollment rate (LNER), income (LNGDP), female employment (LNSE), age dependency ratio (LNADR) and infant mortality rate (LNIM) for all three countries. Infant mortality ratewhich is found to be positively related to female fertility for Indonesia and the Philippines are also supported by Friedlander and Silver (1967), Defo (1998) and Yamada (1985) among others (see Table 5). However, infant mortality is found to be negatively related to female fertility for Thailand. The income series is only significant for Thailand, which has an inverse relationship with the female fertility rate is supported by Narayan and Peng (2003). For Indonesia and Philippines, female secondary education has a positive relationship with female fertility rate. This corresponds to Cochrane (1979) who found that a positive relationship between those variables exists in rural places. On the other hand, Thailand's female secondary education which has an inverse relationship with the female fertility rate is confirmed by Cochrane (1979), Heer (1966), Friedlander and Silver (1967), Panopoulou and Tsakloglou (1999) and Teguh (2009).

Table 5: Long-Run Equation

\begin{tabular}{lccc}
\hline Variables & Indonesia (1980-2014) & Philippines (1980-2014) & Thailand (1980-2013) \\
\cline { 2 - 4 } & \multicolumn{3}{c}{ Dependent variable: LNFR } \\
\hline Intercept & -4.613 & 3.634 & -6.652 \\
LNER & $0.382^{* *}$ & $0.200^{* * *}$ & $-0.175^{* *}$ \\
& {$[-2.238]$} & {$[-4.478]$} & {$[2.123]$} \\
LNGDP & & & $-0.700^{* * *}$ \\
& -0.076 & 0.016 & {$[12.226]$} \\
LNSE & {$[0.316]$} & {$[-1.081]$} & -0.033 \\
& $0.766^{* * *}$ & $-0.119^{* * *}$ & {$[0.356]$} \\
LNADR & {$[-3.479]$} & {$[3.171]$} & $0.368^{* * *}$ \\
& $-4.396^{* * *}$ & $0.769^{* * *}$ & {$[-3.341]$} \\
LNIM & {$[7.289]$} & {$[-15.228]$} & $-0.329^{* *}$ \\
& $2.812^{* * *}$ & $0.337^{* * *}$ & {$[2.227]$} \\
\hline
\end{tabular}

Note: ${ }^{*}{ }^{* *}$ and ${ }^{* * *}$ denote statistical significance at $1 \%, 5 \%$ and $10 \%$ respectively. 
The female employment rate in services is found to be directly related to female fertility rate for Indonesia, and this is consistent with the results for the study done by Da Rocha and Fuster (2006) where they stated that a positive relationship is possible in an environment with a low probability of finding a job. However, for the Philippines inverse relationship between employment in services and female fertility is supported by Broeck and Martens (2014) and Da Rocha and Fuster (2006) in instances where the probability of finding jobs is higher with the modernization in the Philippines economy where the services sector contributed 54 percent to total employment and 57 percent of GDP in 2014 (NEDA, 2015). For Indonesia, age dependency ratio has a negative relationship with the female fertility rate as per thetheory (see, for example, Bryant, Faruqee, Velculescu and Arbatli [2004] on the study of young ADR; Hock and Weil [2012] focusing on old ADR). However, for the Philippines and Thailand, a significant positive relationship can be observed.

Lastly, the graph of CUSUM and CUSUMSQ statistics are plotted (in Figure 2). CUSUM statistics are stable for all three countries studied, within the critical bounds at 5\%. However, CUSUMSQ are found to be stable only for Indonesia and the Philippines. This supports the fact that the estimated ECM models are stable over the sample period 1980-2014 for the two countries. Thailand's CUSUMSQ crossed the critical bounds during the period of approximately 2000-2001. This might be due to a flood disaster in Hat Yai at the end of 2000. The disaster killed at least 32 people, injuring about 1700, and causing severe damage to property with and overall cost of damage to the city estimated to be roughly 13,824.67 million Baht (Assanangkornchai, Tangboonngam, \& Edwards, 2004). 
Dynamics of Female Fertility in Indonesia, Thailand and the Philippines, 1980-2014

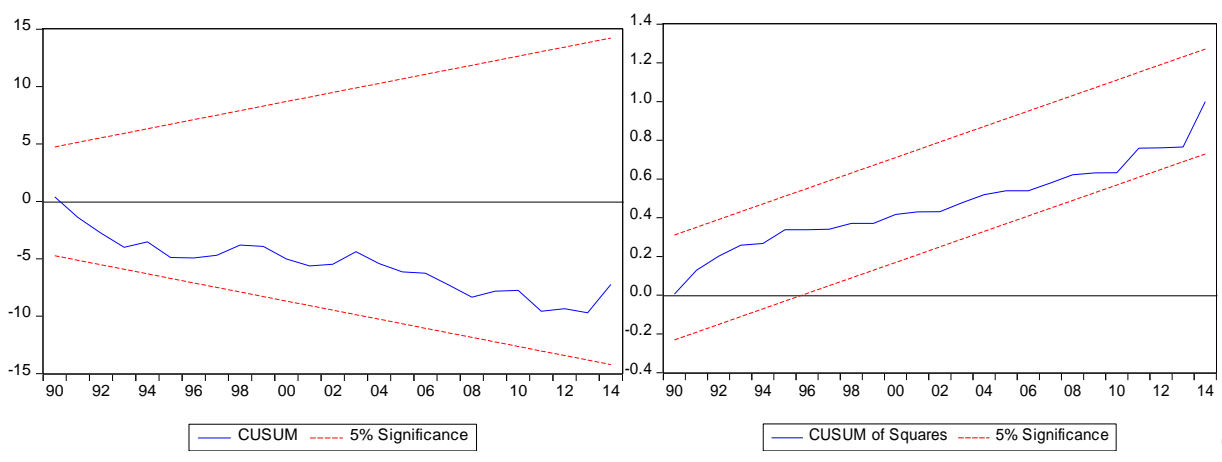

(a)

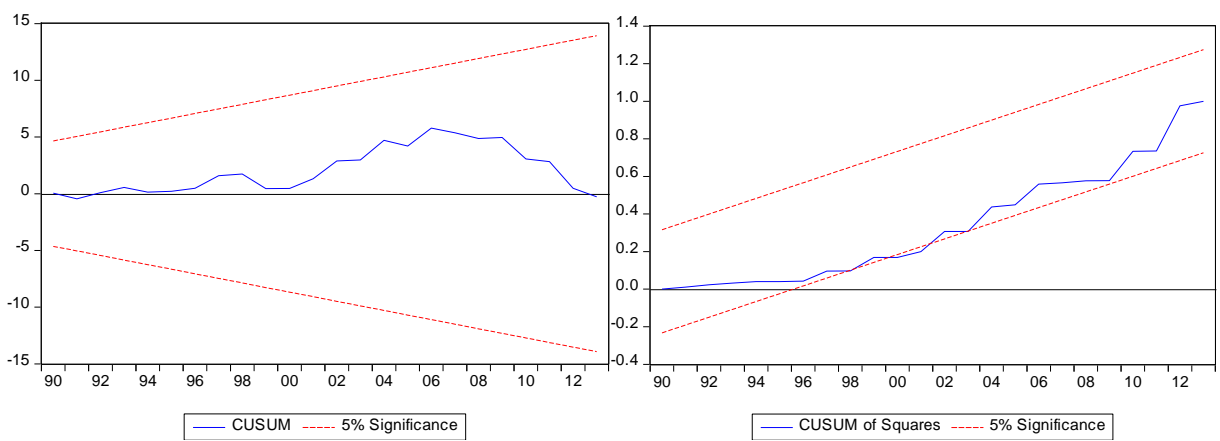

(b)

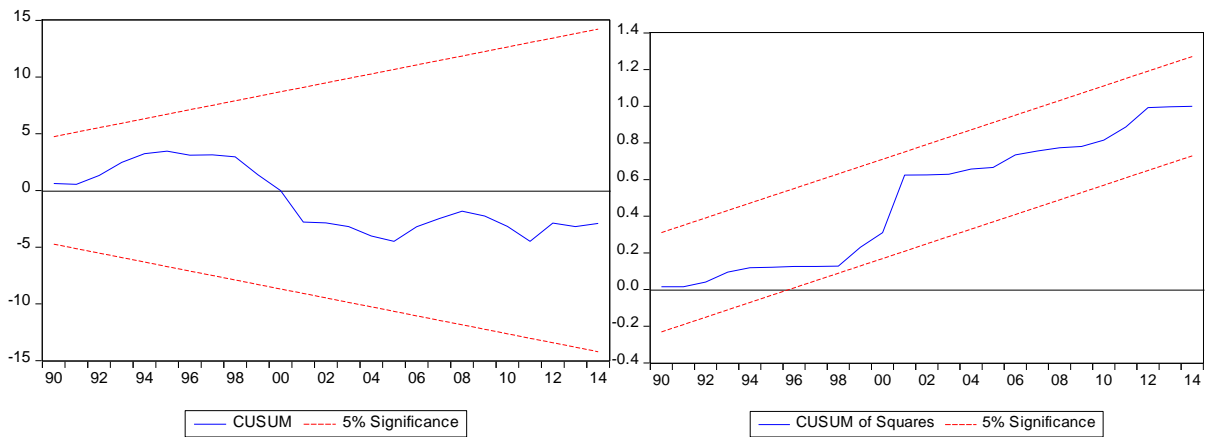

(c)

Figure 2: (a) CUSUM and CUSUMQ Stability Tests for Indonesia. (b) CUSUM and CUSUMQ Stability Tests for Thailand. (c) CUSUM and CUSUMQ Stability Tests for the Philippines 


\section{Conclusion}

Past researches on the relationship between female fertility with infant mortality, income, education, employment and age dependency ratio resulted in mixed outcomes. Thus, it is vital to examine those links within the con text of ASEAN-3, a region experiencing a rapid decline in female fertility. For this purpose, the Johansen cointegration and vector correction estimation are employed using data for the period from 1980-2014 for Indonesia and the Philippines and from 19802013 for Thailand. The main empirical findings of the study can be summarized as follows: First, a long-run relationship is evident between female fertility, infant mortality, income, education, employment and age dependency ratio for Indonesia, Thailand and the Philippines. Second, we identify three major determinants of female fertility for Indonesia as female education (proxied by female secondary enrolment ratio), age dependency ratio and infant mortality ratio which is in line with the theory. For the Philippines, two important variables that determine female fertility and is in accordance with the theory are employment variable (proxied by female employment in services) and infant mortality. For Thailand, two main determinants of female fertility include education and income which is in accordance with the theory. Thirdly, we found a deviation of fertility rate from the short-run to the long-run equilibrium for the three countries being analysed, with the highest and lowest speed of adjustment recorded for the Philippines and Indonesia respectively.

\section{References}

Al-Qudsi, S. (1998). The Demand for Children in Arab Countries: Evidence from Panel and Count Data Model. Journal of Population Economics, 11(3), 435-452. Assanangkornchai, S., Tangboonngam, S., \& Edwards, J. (2004). The

Flooding of Hat Yai: Predictors of Adverse Emotional Responses to A Natural Disaster. Stress and Health, 20, 81-89.

Baharumshah, A. Z., Lau, E., \& Khalid, A. M. (2006). Testing Twin Deficits Hypothesis Using VARs and Variance Decomposition. Journal of the Asia Pacific Economy, 11(3), 331-354.

Becker, G. S. (1960). Demographic and Economic Change in Developed Countries. Columbia: Columbia University Press.

Bryant, R., Faruqee, H., Velculescu, D. \& Arbatli, E. (2004). Fertility Declines and Youth Dependency: Implications for the Global Economy. Brookings. Retrieved from https://www.brookings.edu/research/fertility-declines-andyouth-depen dency-implications-for-the-global-economy-2/ 
Cobbe, J., \& Boediono. (1993). Education, Demographics, the Labor Market, and Development: Indonesia in the Process of Transition? Journal of Asian and African Studies, 28, 1-29.

Cochrane, S. H. (1979). Fertility and education: what do we really know? Baltimore, MD: The Johns Hopkins University Press. Retrieved from http://documents.worldbank.org/curated/en/550621468765918708/Fertilityand-education-what-do-we-really-know

Da Rocha, J. M., \& Fuster, L. (2006). Why are Fertility Rates and Female Employment Ratios Positively Correlated Across OECD Countries? International Economic Review, 47(4), 1187-1222.

Defo B.K. (1998). Fertility Response to Infant and Child Mortality in Africa with Special Reference to Cameroon in Montgomery MR, Cohen B, (eds) From Death to Birth : Mortality Decline and Reproductive Change. National Research Council (US) Committee on Population; Washington (DC): National Academies Press (US).

De Tray, D. (1973). Child Quality and the Demand for Children. The Journal of Political Economy, 81(2P2), 70-95.

Engle, R. F., \& Granger, C. W. J. (1987). Cointegration and Error Correction Term: Representation, Estimation and Testing. Econometrica, 55, 251-276.

Friedlander, S., \& Silver, M. (1967). QuantitativeStudy ofDeterminants of Fertility Behaviour. Demography, 4(1), 30-70.

Granger, C. W. J. (1986). Development in the Study of Cointegrated Economic Variables. Oxford Bulletin of Economics and Statistics, 48, 213-228.

Gubhaju, B. (2007). Fertility Decline in Asia: Opportunities and Challenges. The Japanese Journal of Population, 5(1), 19-42.

Hock, H., \& Weil, D. (2012). On the Dynamics of the Age Structure, Dependency, and Consumption. Journal of Population Economics, 25(3), 1019-1043.

Hull, T. H., \& Hull, V. J. (1977). The Relation of Economic Class and Fertility: An Analysis of Some Indonesian Data. Population Studies, 31, 43-57.

Johansen, S., \& Juselius, K. (1990). Maximum Likelihood Estimation and In ference on Cointegration - with Applications to the Demand for Money. Oxford Bulletin of Economics and Statistics, 52, 169-210.

Juselius, K. (1996). An Empirical Analysis of the Changing Role of the German Bundesbank after 1983. Oxford Bulletin of Economics and Statistics, 58, 791-819.

Kim, J. (2016). Female education and its impact on fertility. IZA World of Labor. 110. Available at https://wol.iza.org. 
Maralani, V. (2008). The Changing Relationship between Family Size and Education Attainment Over the Course of Socioeconomic Development: Evidence from Indonesia. Demography, 45(3), 693-717.

Masih, A. M. M., \& Masih, R. (1999). Is A Significant Socio-Economic Structural Change A Prerequisite for 'Initial' Fertility Decline in the LDCS? Evidence from Thailand Based On A Multivariate Cointegration/Vector Error Correction Modeling Approach. Population Economics, 12, 463-487.

Myrskylä, M., Kohler, H. P., \& Billari, F. C. (2009). Advances in Development Reverse Fertility Declines. Nature, 460, 741-743.

Narayan, P. K., \& Peng, X. (2003). Econometric Analysis of the Determinants of Fertility in China, 1952-2000. Clayton, Victoria: Monash University.

National Research Council. (2000). Beyond Eight Billion. Washington, DC: National Academy Press.

NEDA. (2015). The Philippine Services Sector and APEC. Retrieved from http://www.neda.gov.ph

Panopoulou, G., \& Tsakloglou, P. (1999). Fertility and Economic Development: Theoretical Considerations and Cross-Country Evidence. Applied Economics, 31(11), 1337-1351.

Schultz, T. P. (2001). The Fertility Transition: Economic Explanations. Economic Growth Center Discussion Paper No. 833. Retrieved from https://ssrn.com/abstract=286291

Shapiro, D (1996). Fertility Decline in Kinshasa. Population Studies, 50, 89-103.

Subramaniam, T., \& Baharumshah, A. Z. ( 2011). Unemployment and Speed of Adjustment in ASEAN-3 Economies: A Cointegration Analysis. The Singapore Economic Review, 56(3), 327-347.

Subramaniam, T., Loganathan, N., \& Devadason, E. S. (2018). Determinants of Female Fertility in ASEAN-5: Empirical Evidence from Bounds Cointegration Test. Singapore Economic Review, 63(3), 593-618

Szreter, S. (1993). The Idea of Demographic Transition and the Study of Fertility Change. A Critical Intellectual History. Population and Development Review, 19(4), 659-701.

Teguh, D. (2009). The Determinants of Fertility in Southeast and South Asian Countries: An Analysis on Panel Data. Journal of Economic Cooperation and Development, 37 (3), 1-22. Retrieved from https://mpra.ub.unimuenchen.de/41412/

Van den Broeck, G., \& Maertens, M. (2014). Does female employment reduce fertility rates? Evidence from the Senegalese horticultural export sector. Triennial Conference of the European Association of Agricultural Economists. Ljubljana: European Association of Agricultural Economists. 
World Development Indicators (2017). Retrieved from http://databank.worldbank.org/data/reports.aspx? source=world-development-indicators\#

Yamada, T. (1985). Causal Relationships between Infant Mortality and Fertility in Developed and Less Developed Countries. Southern Economic Journal, 52(1), 364-370. 